\title{
OS SONHOS ACORDADOS E A OBRA DE ARTE: FREUD NO PERCURSO DE ERNST BLOCH ${ }^{1 *}$
}

\section{DAYDREAMS AND THE WORK OF ART: FREUD IN ERNST BLOCH'S PATH}

\author{
Ubiratane de Morais Rodrigues \\ https://orcid.org/0000-0001-8101-9616 \\ ubiratanerodrigues@gmail.com \\ Universidade Federal do Maranhão, Brasil
}

RESUMO $O$ objetivo desde artigo é demonstrar como Ernst Bloch se apropria das reflexões de Freud sobre os sonhos acordados para sua filosofia. A partir de uma fenomenologia dos sonhos acordados, Bloch constrói sua hermenêutica da obra de arte de caráter utópico. Isso é possível desde a desvinculação ontológica entre sonhos noturnos e sonhos acordados. Dessa operação, pode-se concluir que os sonhos acordados na filosofia de Bloch é uma chave hermenêutica que inquire o sentido das obras de arte desde um ainda-não-consciente do futuro nas obras do passado.

Palavras-chave Sonhos Acordados. Sonhos Noturnos. Obra de Arte.

1 Este artigo faz parte de minha tese de doutorado intitulada A estética da pré-aparência (Vor-Schein) como antecipação transgressiva em Ernst Bloch defendida no Programa de Pós-Graduação em Filosofia da Universidade de São Paulo sob a orientação do Prof. Dr. Oliver Tolle em fevereiro de 2020. Para seu desenvolvimento teve o auxílio de uma bolsa de estudos da Fundação de Amparo à Pesquisa e ao Desenvolvimento Científico e Tecnológico do Maranhão - FAPEMA.

* Artigo submetido em 18/08/2020. Aprovado em 10/12/2020. 
ABSTRACT The purpose of this article is to demonstrate how Ernst Bloch appropriates Freud's reflections on daydreams for his philosophy. From a phenomenology of daydreams, Bloch builds his hermeneutics of the utopian work of art. This is possible since the ontological separation between night dreams and daydreams. From this operation, it can be concluded that the daydreams in Bloch's philosophy are a hermeneutic key that questions the meaning of the works of art from a not-yet-conscious of the future in the works of the past.

Key words Daydreams. Night Dreams. Work of art. Ernst Bloch.

\section{Introdução}

Os sonhos inspiram a criação poética e artística, como, por exemplo, $I l$ Trillo del Diavolo, obra composta pelo músico italiano Giuseppe Tartini (16921770), que traz no fundo de sua criação o elemento do sonho noturno. Esse tipo de sonho é, sem dúvida, o mais referenciado quando se associam arte e sonho. Contudo, existe outro tipo de sonho que também inspira as artes e a literatura; são denominados sonhos diurnos, sonhos de vigília, ou, ainda, sonhos despertos. É a esse tipo de sonho que Ernst Bloch se dedica para demonstrar, entre outras coisas, a importância destes na relação direta entre arte e utopia, pois os sonhos diurnos são a base de sua filosofia da esperança. Ora, se os sonhos diurnos e noturnos produzem "matéria" para a obra de arte, quais seriam as diferenças entre as imagens produzidas pelos primeiros e as imagens produzidas pelos segundos? Ou melhor: por que Ernst Bloch prioriza os sonhos diurnos na relação arte-utopia? O argumento defendido neste artigo é que as obras de arte inspiradas pelo sonho diurno possuem um valor ontológico de verdade, uma vez que suas imagens são produzidas no limiar histórico do advento do futuro, do novo, possuindo elementos materiais concretos que permitem pensar e antecipar dias melhores no mundo em processo. Para Bloch, os sonhos noturnos, ao contrário dos diurnos, não nos garantem uma verdade ontológica ligada ao real, já que são imagens ligadas ao inconsciente, imagens que passam por um processo de codificação de um desejo reprimido e que não são claras, muitas vezes, nem para o sujeito que as produz no sonho. Portanto, pelo fato de que o sujeito não tem o controle da produção das imagens no sonho noturno, o seu valor ontológico de verdade está comprometido.

A compreensão desse argumento passa pelo debate entre Bloch e Freud e a preferência deste último pelo sonho noturno, assim como as críticas de Bloch a esta prioridade. Sabe-se que a preocupação de Freud com os sonhos é de 
caráter clínico-terapêutico; as imagens oníricas lhe servem de material para a compreensão e o tratamento de sintomas psicológicos. Para Bloch, os sonhos, particularmente os sonhos despertos, têm importância teórico-prática.

\section{Os sonhos diurnos: Freud}

Os sonhos diurnos são trabalhados teoricamente pela primeira vez na obra $A$ interpretação dos sonhos de Freud. Bloch parte das descobertas freudianas sobre essa categoria para levá-las às últimas consequências teóricas para sua filosofia ${ }^{2}$. O sonho acordado não é uma "descoberta" de Freud, que reconhece que os poetas já o conheciam. Assim, qual é a importância de Freud em relação a esse conceito para as questões estéticas? Mesmo Freud tendo apresentado os sonhos diurnos como matéria essencial da arte, são os sonhos noturnos que ganham relevância em sua teoria. A tese freudiana de que esses sonhos são realizações de desejos recalcados, lembranças da infância ou do dia anterior, possuem uma lógica interna que Freud denominou elaboração onírica, compreendendo as seguintes fases: condensação, deslocamento, figurabilidade e elaboração secundária. Em síntese, a condensação (Freud, 2017, pp. 301-327) é o processo do sonho em que o material onírico passa por uma compressão: omissão de elementos. Tem-se aí a deformação do conteúdo e a introdução do conteúdo latente no conteúdo manifesto. No deslocamento (Freud, 2017, pp. 328-332), o sentido do sonho está em outro lugar, ou seja, há um deslocamento da atenção do lugar mais importante do sonho para outro sem importância, disfarçando o verdadeiro sentido do sonho. A figurabilidade (Freud, 2017, pp. 333-362) é a transformação que o material do sonho sofre para fazer as imagens aparecerem; ela faz a combinação de vários elementos em um único manifesto. Todo esse trabalho do sonho, somado à última etapa, que é a elaboração secundária, tem como finalidade deformar a representação do desejo, disfarçá-lo, apresentá-lo de outra maneira através do sonho. O sonho é, assim, um desejo reprimido e codificado.

É na última fase do trabalho do sonho, isto é, na elaboração secundária, que surge o problema e os primeiros esboços de Freud sobre os sonhos diurnos. No

2 A título de sugestão e abertura para novas pesquisas sobre este tema na tradição marxista, o autor deste artigo reconhece que o tema dos sonhos não é uma apropriação original e exclusiva de Ernst Bloch, uma vez que o pensamento de Freud influenciou diretamente os filósofos e filósofas do século XX. Entretanto, destacamos que no processo de pesquisa sobre os sonhos diurnos no pensamento de Bloch ficou explícito que a apropriação crítica desde conceito é uma originalidade do filósofo de Tübingen. Trabalharemos na exposição dessa assertiva em um próximo trabalho, no qual será possível apresentar comparativamente a influência de Sigmund Freud na obra de Bloch e de outros filósofos da tradição marxista do século XX. 
tratamento teórico do capítulo VI “A elaboração dos sonhos” de $A$ interpretação dos Sonhos, Freud estabelece uma relação fundamental entre os sonhos diurnos e a criação poética, ou criação artística. Nessa fase, Freud se depara com o problema do pensamento normal influenciando os sonhos noturnos e, ao mesmo tempo, associa os sonhos diurnos aos sintomas da histeria,

\begin{abstract}
Há um caso em que o trabalho de construir uma fachada para o sonho, por assim dizer, lhe é poupado em grande parte pelo fato de tal estrutura já ser encontrada pronta no material dos pensamentos oníricos, onde espera por utilização. Costumo chamar de fantasia o elemento dos pensamentos oníricos que tenho em vista; talvez evite mal-entendidos se identificar logo o sonho diurno como seu análogo da vida de vigília. [...] $\mathrm{O}$ estudo das psiconeuroses levou à descoberta surpreendente de que essas fantasias ou sonhos diurnos são os estágios preliminares mais imediatos dos sintomas histéricos - pelo menos, de toda uma série deles; [...] (Freud, 2012, p. 517, itálico do autor; negrito nosso).
\end{abstract}

Ainda sobre os sonhos diurnos, Freud acrescenta que eles seriam simplesmente atalhos para uma melhor e mais rápida compreensão dos sonhos noturnos. Essa tese, junto com as supracitadas, levou Bloch a criticar Freud e a estabelecer uma teoria onírica para dissociar os sonhos diurnos dos sintomas de histeria, fornecendo suporte para a compreensão do correto lugar dos sonhos noturnos e diurnos em sua obra $O$ princípio esperança. A partir disso, podemos entender como as imagens produzidas pelos sonhos despertos têm um estatuto ontológico cujo valor de verdade não é apenas subjetivo, e, portanto, relegado ao julgamento do ilusório, mas também objetivo, dadas as determinações concretas utilizadas na produção das imagens. Se os sonhos diurnos são prelúdio da arte, como intuído por Freud e aprofundado teoricamente por Bloch, então, para que as imagens, produtos da criação artístico-poética, tenham teor de verdade e suas interpretações não se tornem quimeras e/ou sintomas patológicos, tais imagens devem estar bem fundamentadas naquilo que Bloch denominou possível-real, como veremos mais à frente.

Retornando aos argumentos sobre a elaboração secundária, destaca-se que em Freud os sonhos diurnos possuem fantasias conscientes e inconscientes, mas que não podem ser alcançadas na vigília, uma vez que elas são reprimidas. Duas questões chamam atenção: a primeira é o reconhecimento de Freud da importância dos sonhos diurnos para os "escritores imaginativos" na produção de suas obras. Uma referência citada por ele é Alphonse Daudet em Le Nabab. Mas não faltam outros exemplos nem em A Interpretação dos sonhos, nem em outros escritos de Freud (2015). Outro ponto relevante é o reconhecimento de propriedades semelhantes entre os dois tipos de sonhos, o noturno e o diurno; mesmo guardando as suas devidas dimensões ontológicas, Freud afirma em 
ambos sua tese central: o sonho é a realização de um desejo. Os sonhos diurnos para Freud possuem as seguintes características: são realizações de um desejo reprimido; estão na base das experiências e lembranças infantis e beneficiam-se do relaxamento da censura. Se lermos atentamente, Freud faz um deslocamento das características dos sonhos noturnos para os sonhos diurnos, mas não em sua importância e seu valor terapêutico. Todavia, reconhece seu grande valor criativo, que permite à elaboração secundária se apropriar de fantasias dos sonhos diurnos para moldar de maneira semelhante os sonhos noturnos.

$\mathrm{Na}$ "elaboração secundária" que atribuímos ao nosso quarto fator formador de sonhos na relação com o conteúdo onírico, encontramos a mesma atividade que, na criação de sonhos diurnos, pode se manifestar sem ser inibida por outras influências. Poderíamos dizer simplesmente que nosso quarto fator procura criar algo como um sonho diurno a partir do material que lhe é oferecido (Freud, 2012, p. 518).

A elaboração secundária tem liberdade no processo de apropriação dos elementos da fantasia diurna para aplicá-los no conteúdo do sonho noturno, por isso a conclusão de Freud é de que existem repetições de fantasias diurnas em alguns sonhos noturnos, fantasias essas que permaneceram inconscientes. Entre a elaboração secundária e os sonhos diurnos existe um intercâmbio de conteúdos e uma semelhança na atuação de criar algo "como se", ou seja, uma semelhança na elaboração das fantasias. Essa semelhança ocorre porque a elaboração secundária é responsável por um ordenamento lógico e coerente dos sonhos noturnos, garantindo a inteligibilidade da fantasia para que as imagens tenham um sentido no sonho noturno. Contrariamente a Freud, as imagens em Bloch não têm apenas sentido, tampouco são apenas verdades psíquicas, elas têm teor de verdade concreta quando produzidas pela fantasia objetiva, pois o que está em jogo, para Freud, é desvelar as fantasias inconscientes nas imagens dos sonhos noturnos, e isso explica de certa forma porque não existe uma maior exploração e sistematização dos sonhos diurnos em sua obra de 1900. Outra diferença importante, entre a elaboração secundária de Freud e os sonhos diurnos para Bloch, é que enquanto no primeiro é a falha no processo da elaboração secundária que provoca desconexões no sonho noturno, e se torna fundamental para a análise deste, no segundo, ao contrário, os sonhos despertos vão até o fim sem interrupções exteriores, ou, se elas existem, existem enquanto vontade do sonhador. Entretanto, isso não significa dizer que os sonhos diurnos, para Bloch, sempre tenham necessariamente começo, meio e fim ordenados.

Freud reconhece as artes como prenhes de sonhos, ou pelo menos que as imagens que as representam possuem uma figuração concreta daquilo que há na vida onírica. A questão de fundo é a associação da fantasia com o "como se". O 
sonho de Maury, um caso relatado por Freud em A interpretação dos sonhos, serve como exemplo; a explicação deste sonho, que passa pela questão do tempo e da fantasia já pronta no inconsciente e preparada em vigília, apresenta um intricado argumento entre fantasia e criação poética. Na interpretação deste sonho, Freud diferencia entre fantasia e imaginação: esta não está impregnada de desejo como aquela. Ele descobre duas características presentes nos sonhos diurnos, diferenciando-os entre sonhos de ambição e sonhos eróticos, o que será desenvolvido por ele em seu escrito O poeta e o fantasiar. Em outras palavras, existem sonhos cuja fantasia inconsciente foi produzida ao longo da experiência de vida e das suas diversas relações com o mundo; no sonho de Maury, por exemplo, ela foi produzida pela literatura e pela história da Revolução Francesa. O desafio é pensar a passagem do "como se" (ele pensasse) para o "deve ser assim", "poderia ser assim", "pode ser assim".

Faz-se necessária ainda uma distinção importante entre aquilo que Freud chama de sonho diurno e o sonho diurno fundamentado por Bloch. Enquanto o primeiro designa o sonho diurno como devaneio "[...] como pensamento livremente divagante ou fantástico, em oposição à reflexão intencionalmente dirigida" (Freud, 2011, p. 323), para Bloch há uma intencionalidade concreta que guia o sonho diurno. E ainda, enquanto em Freud as fantasias são complicadas, deformadas, mal-entendidas pelas instâncias psíquicas conscientes, em Bloch são as instâncias da "consciência" que moldam as fantasias dos sonhos diurnos; portanto, estes não são devaneios. A própria caracterização da pessoa devaneando, caminhando ligeiro, sorrindo repentinamente, falando sozinha correspondem em Freud a sintomas histéricos. Ao contrário, em Bloch, os sonhos diurnos não servem como etiologia das neuroses ou das psicopatologias, eles devem ser comunicados e colocados em prática no mundo real, não devem ficar restritos à esfera psíquica do sonhador. Bloch não faz uma etiologia e sim uma fenomenologia dos sonhos diurnos, embora não se possa descartar o diagnóstico freudiano de que "em circunstâncias favoráveis é possível flagrar uma fantasia inconsciente desse tipo na consciência” (Freud, 2015, p. 341), ou seja, existe um tipo de devaneio que se encaixa nas patologias estudadas por Freud. Mas ao contrário deste, o sonho diurno para Bloch "[...] pode proporcionar ideias que não pedem interpretação, e sim elaboração, ele constrói castelos de vento com as plantas já desenhadas e nem sempre meramente fictícias" (Bloch, 2005, p. 88).

Freud reconhece como funciona nosso pensamento de vigília, que este estabelece ordem, estrutura e relações conforme as nossas expectativas. Entretanto, sua resistência aos sonhos diurnos é demonstrada por meio da desconfiança com que trata a elaboração secundária, como ele mesmo diz: 
"para nossa interpretação, fica a regra de desconsiderar em todos os casos a coerência aparente do sonho, por ser de origem suspeita, e, partindo tanto do claro quanto do confuso, tomar o mesmo caminho de retorno ao material onírico" (Freud, 2012, p. 526). A elaboração secundária contribui na "intensidade plástica de cada uma das transformações oníricas" (ibidem, p. 526). Para Bloch, essa característica é fundamental nos sonhos diurnos, porque é a intensidade plástica dos elementos do sonho que alargam a realidade ao horizonte em devir. Mesmo sabendo da possibilidade de os sonhos diurnos fracassarem na realidade vivencial do mundo, Bloch não deixa de afirmar que existem sonhos diurnos que conservaram "[...] a coragem e a esperança dos seres humanos, não desviando os olhos do real, mas, ao contrário, encarando a sua evolução e o seu horizonte" (Bloch, 2005, p. 79).

Ora, se segundo Freud, na elaboração secundária estamos no limiar do despertar do sono, no momento em que a consciência anuncia o alvorecer, nos sonhos diurnos de Bloch estamos no limiar, mas no limiar do novo, no horizonte do futuro. Percebe-se que há em Bloch um movimento dos sonhos diurnos como expansão para a frente, que é desenvolvido de forma diferente por Freud, inclusive na relação entre fantasia e a consciência. Para Freud, a consciência desperta é uma senhora que atribui grande importância à razão e à lógica. Ele utiliza uma anedota de Havelock Ellis (1859-1939) para ilustrar a relação entre a consciência adormecida e a desperta: "[...] 'Lá vem nossa mestra, a consciência desperta, que dá um valor extraordinário à razão, à lógica e afins. Rápido! Pega as coisas, coloca-as em ordem, não importa qual, antes que ela entre para tomar posse do lugar"' (Freud, 2012, p. 527). Diante da crítica à consciência desperta, Freud afirma que "[...] os pensamentos oníricos são formados de maneira inteiramente correta e com todo o dispêndio psíquico de que somos capazes" (ibidem, p. 532). Qual então a diferença entre o pensamento onírico e o pensamento da consciência desperta? Segundo Freud, o conteúdo do sonho vem dos pensamentos inconscientes e o trabalho onírico transforma os conteúdos latentes em conteúdos manifestos, ou seja, aqueles pensamentos inconscientes que desconhecemos nas imagens e sons que temos no sonho e que serão interpretados na análise são diferentes de nossa "visão de pensamento de vigília", de nossa racionalidade lógica. Temos assim uma importante tese de Freud:

O trabalho do sonho absolutamente não pensa, calcula ou julga, mas se limita a transformar. Ele admite uma descrição exaustiva se considerarmos as condições que seu produto precisa satisfazer. Esse produto, o sonho, deve sobretudo escapar à censura, e com essa finalidade o trabalho do sonho se serve do deslocamento das intensidades psíquicas, chegando à transvaloração de todos os valores psíquicos [...] (ibidem, p. 533). 
Em outras palavras, estamos diante de duas racionalidades. Freud opta por trabalhar com uma forma particular de pensamento que modela imagens e não argumentos lógico-científicos. Bloch não defende a supremacia irrefutável da consciência, isso o levaria a cair de novo numa racionalidade estéril que ele mesmo critica, mas pensa o sonho diurno enquanto um pré-consciente desperto, que ainda-não-é: ainda não veio a ser. Essa diferença é fundamental, pois enquanto no devaneio freudiano o tempo presente é aquele "[...] em que o desejo é figurado como realizado" (ibidem, p. 563), em Bloch, o sujeito que sonha se lança ao futuro. Os sonhos diurnos têm a dimensão de futuro mesmo estando presos ao sujeito presente.

\section{Sonhos diurnos: Bloch}

A primeira tarefa de Bloch é caracterizar os sonhos noturnos freudianos e os sonhos diurnos que fundamentarão filosoficamente seu projeto utópico concreto, garantindo, assim, aos dois modelos oníricos, seus devidos valores teóricos. Para isso, apropria-se da principal descoberta de Freud: os sonhos são a realização de desejos reprimidos, e não são bolhas de sabão nem oráculos proféticos. Essa apropriação leva-o ao aprofundamento do lado diurno do sonho, que também é a realização de um desejo impedido/reprimido, embora impossibilitado pelas condições do presente, sejam elas materiais ou subjetivas (Ueding, 1974, p. 9). O passo seguinte de Bloch é demonstrar a diferença entre os dois tipos de sonhos e sua opção pelos sonhos diurnos. Mesmo reconhecendo que na consciência utópica também há lugar para os sonhos noturnos, ele aponta neles três características fundamentais que o faz optar pelos sonhos diurnos:

Primeiro, no sono o eu adulto está enfraquecido, não podendo mais censurar o que lhe parece inoportuno. Segundo, da vigília e de seu conteúdo restam apenas as chamadas sobras do dia, isto é, representações associativas bastante inconsistentes, às quais a fantasia onírica se incorpora. Terceiro, em conexão com o eu enfraquecido, o mundo exterior-com suas realidades e propósitos práticos - está bloqueado (Bloch, 2005, p. 81).

Bloch retoma os passos de Freud para demonstrar que além dessas três características, os sonhos noturnos têm como material fundamental as lembranças da infância, a qual ele associa à pré-história, à regressão e ao passado. Outro ponto da crítica blochiana a Freud é em relação à censura, pois o eu censurador não dorme, mas está apenas enfraquecido. Assim, a realização do desejo no sonho é, em grande parte, feita por um simbolismo que o sonhador não consegue compreender sozinho. Isso significa, para nosso autor, que os desejos não são realizados completamente nos sonhos noturnos, como pensou Freud. 
A realização do desejo nos sonhos noturnos por meio dos símbolos encontra na análise dos sonhos feita pela psicanálise o caminho para sua elucidação ou não. Essa interpretação torna-se de início difícil porque o eu está desperto e resiste à análise. Por não ter claro o conteúdo do sonho noturno, Freud, segundo nosso autor, busca através da análise os significados dos sonhos, pois nem mesmo o sonhador conhece os significados por trás dos conteúdos manifestos de seus sonhos. A conclusão de Bloch, sobre os sonhos noturnos, é que eles não trazem nada de novo, mas reforçam apenas o inconsciente como lugar do esquecido e do recalcado. Dito isso, ele avança para outra esfera: os sonhos diurnos.

Ernst Bloch busca garantir uma fundamentação ontológica das imagens presentes nos sonhos diurnos através do enfraquecimento ontológico das imagens dos sonhos noturnos, pois naqueles o eu está desperto e ciente da realidade que os cerca, antecipando imagens que podem ou não ser satisfeitas no mundo real e não somente no mundo onírico, enquanto os sonhos noturnos produzem satisfações em imagens que se esgotam em si mesmas. Mas o que sustenta esse jogo com as imagens? O que faz delas bolhas de sabão ou realização efetiva de desejos? Sua estrutura e conteúdo. Bloch prefere os sonhos diurnos porque "diferentemente do sonho noturno, o sonho diurno desenha no ar repetíveis vultos de livre escolha, e pode se entusiasmar e delirar, mas também ponderar e planejar" (ibidem, p. 88). Os sonhos diurnos, ao contrário dos sonhos noturnos, não dependem de interpretações, estão no campo da elaboração e necessitam da ação, da práxis para a efetivação das imagens antecipadas. As imagens do desejo possíveis de concretizar uma vida melhor, imagens de um mundo e de um humano em processo, ocorrem em sua quase totalidade durante o dia, de olhos abertos, diante das condições concretas e históricas de sua existência. E, nesse caso, mesmo os pequenos sonhos diurnos são importantes por proporcionarem uma antecipação. Entretanto, o foco de Bloch são os sonhos acordados que têm compromisso com o coletivo, aqueles que ultrapassam a mera interioridade do indivíduo e pintam paisagens onde o eu não está só, onde mesmo dizendo Eu, diz-se Nós.

Bloch se esforça para fundamentar uma teoria dos sonhos diurnos descolada da tese freudiana de que os sonhos diurnos são prelúdios do sonho noturno. Como contraponto aos elementos infantis do sonho noturno, temos a marca da juventude nos sonhos despertos e os desejos de mudança, o que o fez estabelecer a relação intrínseca entre os sonhos diurnos e a esperança. Ele tensionou de tal forma os sonhos diurnos que fez deles uma categoria filosófica fundamental na engrenagem de seu pensamento utópico, principalmente na arquitetura de sua 
obra $O$ princípio esperança ${ }^{3}$. Os sonhos diurnos são despertados pela carência, esse princípio gera uma dialética entre sonhos diurnos, desejo e espera, que podem ser sonhos dos mais banais e individuais, como os da infância e da adolescência, bem como os sonhos da maturidade, que podem ser mediados e de caráter utópico ${ }^{4}$. Sendo o princípio a carência, enquanto ela não for extinta não se cessará de sonhar, visto que o humano deseja sempre uma vida melhor ainda ausente. O sonho diurno está em relação com o mundo e, portanto, na esfera da ação. Nesse sentido, uma fenomenologia dos sonhos diurnos é capaz de revelar sua relação direta com a arte, visto que esta é a expressão de uma antecipação, pelo trabalho do artista, no qual primeiro e melhor se concretizam os sonhos diurnos como paisagens do desejo.

O ponto de partida desde a carência do indivíduo por sua incompletude, seu iniciar no mundo sem nada, é uma radicalização na obra de Bloch desde seu primeiro livro de 1918, Espírito da utopia. Em O princípio esperança, o tópico começamos sem nada (Bloch, 2005, p. 29), em primeira pessoa, indica que o eu que se movimenta começa no mundo sem nada. Como então o sujeito começa sem nada e chega aos sonhos diurnos? O que o move para a frente? Arno Münster (2009, p. 76) considera esse "[...] não ter, ainda não ser, ainda não se possuir", a revelação de uma "[...] subjetividade isolada alienada que aspira a uma autorrealização que não pode ainda se concretizar".

É da pulsão mais básica, da autopreservação plasmada primeiramente na fome, que surgem os sonhos diurnos. Eles são a base para a obra de arte utópica, pois levam até o fim as imagens dos desejos pelo ego preservado, cumprem uma função importante na fundamentação subjetiva da esperança, pois a imaginação é o primeiro recurso para ultrapassar as barreiras concretas que impedem a emancipação humana. Por ser o humano prenhe de afetos expectantes, e havendo necessariamente um impulso de autoexpansão em cada ser, seu movimento para a frente não requer somente o trabalho manual, mas precisa antecipar a ação, precisa antecipar uma condição melhor que a existente ${ }^{5}$. Assim, contra

3 Esta afirmação segue Carlos Jordão, para quem o sonho diurno "[...] perpassa toda a argumentação do livro ao tentar dar resposta à questão inconstrutível de nós mesmos, começando com o instante em que nos encontramos ainda dispersos, imersos na 'obscuridade do instante vivido' (das Dunkel des gelebten Augenblickes), numa penumbra que nos envolve provocando angústia, tédio; afetos indefinidos, desconectados, irracionais, pois ainda não temos o que queremos; é o 'diariamente sem saber o amanhã' e que aos poucos se esvai ao vislumbrar que a vida poderia ser diferente do que é." (Machado, 2009, p. 194).

4 Albornoz caracteriza bem esses sonhos mediados: "os sonhos de caráter utópico mais maduro são os que se referem à evolução coletiva: técnico-econômica e sociopolítica. É o âmbito dos sonhos que antecipam o futuro coletivo possível porque ruminam e elaboram as possibilidades atuais incluídas nas relações econômicosociais e políticas do presente: os sonhos de ordens sociais ideais ou alternativas." (Albornoz, 1985, p. 106).

5 Luiz Bicca destaca a relação entre as representações da antecipação e a conservação da vida humana com relação ao trabalho; segundo ele, isso quase não foi debatido com os intérpretes de Bloch. Uma das referências quanto a este tema é Ernest Mandel, citado aqui por Bicca: "a capacidade humana para a antecipação, para 
a redução dos sonhos diurnos aos sonhos noturnos, ele afirma que os sonhos diurnos não são um prelúdio dos sonhos noturnos, uma vez que aqueles forçam a transformação da realidade e são as prolepses da imaginação, o horizonte deles é o futuro. Eles existem como sonhos mais triviais e como aqueles que fundam e sustentam as obras de arte e as transformações sociais e, portanto, estão no âmbito do ainda-não-consciente, estão em processo como o mundo.

Bloch estabelece quatro características principais dos sonhos diurnos: a primeira é o ego preservado na hora do sonho diurno; a segunda é o livre curso da imaginação; a terceira é melhoria do mundo e a quarta é ir até o fim. Assim, para ele, nas duas primeiras características, o sonhador pode controlar suas fantasias, ele pode determinar o objeto de seu sonho, ao contrário do sonho noturno, onde o ego está enfraquecido. Para Bloch (2005, p. 90), “[...] justamente o relaxamento, do qual participa também o eu do sonho diurno, pode resultar numa sensação de exaltação, ainda que questionável, pois então o eu torna-se um ideal desejante para si mesmo, libertado da censura". O relaxamento é nos dois sonhos fundamental, mas enquanto o sonho noturno mergulha no passado, o sonho diurno ruma para o futuro, antecipando-o. Os sonhos diurnos são produtos de uma consciência que almeja uma vida melhor, individual ou coletiva. Diante disso, o ego é preservado e a imaginação é livre e guiada pelo eu consciente e desperto que tem o controle do processo da produção das imagens. Não há deformação, há embelezamento das formas desejadas, os sonhos diurnos apresentam um reforço utopizante que nos leva a assumir compromissos com um mundo melhor, pelo menos como fantasia objetiva, nesse sentido, para que esse mundo melhor venha a ser, o eu deve superar a estaticidade burguesa da sociedade em que vive. Os sonhos diurnos fazem esse primeiro movimento. Assim, concordamos com Zecchi (1978, p. 89, tradução nossa) para quem "a constituição utópica tem seu fundamento na dimensão projectual do sonho com os olhos abertos que se caracteriza em primeiro lugar como possível superação, por parte do eu, da objetividade estática do dado presente, como um possível projeto do diverso".

A terceira característica dos sonhos diurnos é a melhoria do mundo. Essa característica só pode ser realizada se o eu estiver inalterado e diante do livre

a fantasia, está inseparavelmente ligada à sua capacidade para o trabalho social. O homo faber só pode ser homo faber porque é, ao mesmo tempo, homo imaginosus... A base material da capacidade humana para a antecipação, para a imaginação rica em fantasias, é o instinto de autoconservação, isto é, o correlato instintivo da pressão natural para a produção e reprodução da vida material" (MANDEL, Ernest apud Bicca, 1987, p. 76). Esse tema da antecipação e trabalho não é exclusivo de Bloch, ele retoma esse tema de Marx, para quem o homem tem a capacidade de antecipar sua ação, enquanto a abelha, a aranha e os outros animais agem pelo instinto. Bloch não poderia deixar de se apropriar desse tema para a fundamentação de sua antropologia. 
curso da imaginação. É o exercício de saída da própria egoidade e transcender para a alteridade, ou melhor, é quando o sonho diurno passa do sonho de uma vida melhor do eu para o sonho de um mundo melhor para outrem e para nós. Nessa passagem temos a comunicabilidade dos sonhos, já "nos sonhos diurnos, os ideais assumem forma exterior imediatamente, num planejado mundo melhor ou ainda num mundo esteticamente elevado, sem desilusão" (Bloch, 2005, p. 95). No sonho diurno o eu tem compromisso com o coletivo, passa da busca do melhor para a vida privada ao melhor para a vida pública, pois mesmo em sonhos diurnos de natureza individual há interesse coletivo, como por exemplo, o quarto livro das Confissões de Rousseau citado por Bloch (2005, p. 93), que ao comunicar o conteúdo de seu devaneio expressou um mundo melhor e mais bonito para o coletivo.

$\mathrm{O}$ quarto caráter do sonho diurno é ir até o fim. Isso é possível pelo fato de que o ego não está enfraquecido e é senhor do processo de formação das imagens do desejo, ou seja, ele permite o livre curso da imaginação por querer o melhor para si e para o mundo. A realização do desejo nos sonhos diurnos é levada de forma consciente até o fim. Eles têm um correlato com o real, com o mundo exterior, por isso, "composições significativas da fantasia do sonho diurno não produzem bolhas de sabão: elas abrem janelas e, por trás destas, o mundo do sonho diurno é no mínimo uma possibilidade a que se pode dar forma" (Bloch, 2005, p. 100). Isso é possível porque no sonho diurno o eu projeta sem interrupções as imagens do desejo, imagens autênticas possíveis de comunicação e realização. Por isso Bloch estabelece o sonho diurno como expansão do si-mesmo e do mundo para a frente, e reconhece o anseio como característica das duas espécies de sonhos. Todavia, ao contrário dos sonhos noturnos, os sonhos diurnos têm um alvo e o buscam pela força da imaginação em estado desperto. Estas quatro características fundamentais dos sonhos diurnos são subsídios da fundamentação de uma antropologia transgressiva e dos sonhos diurnos como modeladores da arte. Isso leva Bloch a afirmar que a partir do sonho diurno a arte possui uma natureza utópica "[...] não para tudo dourar levianamente e sim para ter dentro de si também a privacio, que com certeza não será superada apenas pela arte mas não será esquecida por ela, sendo envolvida pela alegria como uma forma vindoura" (ibidem, p. 96). 


\section{Os sonhos diurnos como prelúdio da arte}

Freud sinalizou que os sonhos diurnos são, além de prelúdio dos sonhos noturnos, prelúdio da arte ${ }^{6}$. Essa tese Bloch aprofundará a partir das quatro características do sonho diurno somadas às críticas feitas às características do sonho noturno. Diante da crítica de Bloch a Freud quanto à relação entre sonho diurno e arte, faz-se necessário analisarmos o texto freudiano O poeta e o fantasiar (Der Dichter und das Phantasieren) publicado na revista Neue Revue, de 1908.

Questionando a região de onde os poetas retiram seus temas e como sua produção toca os homens, ou ainda, como somos afetados por suas obras, Freud nos coloca no cerne da pergunta a respeito da inspiração artística. Segundo ele, nem mesmo o Dichter (o poeta ou escritor no sentido amplo do termo) consegue nos explicar suas inspirações, e mesmo se pudesse isso não faria de nós poetas. Assim, a criação poética permanece um mistério para nós, pois os processos imaginativos nos são ocultos, embora sejam possíveis algumas explicações e interpretações sobre arranjos criativos da produção literária. $\mathrm{Na}$ análise de Freud, a fantasia poética e a atividade de brincar das crianças lhe parecem comuns ao Dichter, isso "[...] na medida em que ela cria seu próprio mundo, melhor dizendo, transpõe as coisas do seu mundo para uma nova ordem, que lhe agrada" (Freud, 2015, p. 54). O ato de brincar da criança é uma atividade séria, ou seja, a seriedade não é o oposto da brincadeira, mas o da realidade. Ora, a imaginação está em plena atividade no ato de brincar e a seriedade nesse ato é um elemento perceptível pelos adultos. A criança povoa de elementos imaginativos a realidade, fazendo uma ponte entre sua brincadeira e o mundo concreto. No argumento de Freud, tem-se a diferença entre o Dichter e as crianças, entre o brincar e o imaginar: "o poeta faz algo semelhante à criança que brinca; ele cria um mundo de fantasia que leva a sério, ou seja, um mundo formado por grande mobilização afetiva, na medida em que se distingue rigidamente da realidade" (ibidem, p. 54). Essa afinidade entre o brincar e o fantasiar é sustentada pela língua alemã: brincadeira/jogo (Spiel): comédia (Lustspiel), tragédia (Trauerspiel), ator (Schauspieler).

O Dichter necessita do mundo concreto para suas criações, e nesse sentido ele também brinca. A questão do mundo fantasioso (poético) do Dichter tem consequências para sua produção, pois as coisas banais, dolorosas do mundo

6 Ueding (1974, p. 8) aponta uma estreita relação entre arte e sonho na estética europeia, e, mesmo reconhecendo a importância de Freud para essa relação, aponta juntamente com Bloch os limites freudianos dessa relação, principalmente quando ela é pensada por intermédio dos sonhos diurnos e toda a crítica blochiana aos limites do inconsciente freudiano e sua teoria da arte sem conexão com a realidade. 
real podem vir a ser prazerosas para os espectadores do Dichter. Segundo Freud, quando a idade avança, há uma substituição da brincadeira pela fantasia, então, em vez de brincar, o adulto forma seus sonhos diurnos. O adulto, ao contrário da criança, esconde suas fantasias, pois nela haveria desejos que não podem ser revelados. Freud parte de suas experiências clínicas para suas especulações sobre o fantasiar e os sonhos diurnos, chegando à conclusão de que a fantasia para ele surge da carência, da insatisfação, da infelicidade, pois os "desejos insatisfeitos são as forças impulsionadoras [Triebkräfte] das fantasias, e toda fantasia individual é uma realização de desejo, uma correção da realidade insatisfatória" (ibidem, p. 57). Não é esse o mesmo ponto de partida de Bloch? Sim, é a carência, mas, ao contrário de Freud, Bloch parte da fome, da carência mais básica, para pôr o humano em movimento.

Freud divide o que nos impulsiona, neste escrito em análise, em duas classes: o erótico e a ambição. Há neles uma imbricação, já que existiria sempre um desejo erótico por trás do desejo de ambição, o que faz Freud intuir a necessidade do adulto de esconder suas fantasias. Assim, para ele, os sonhos diurnos, ou fantasias, são marcados pelo tempo e pelos processos dinâmicos da vida. Isso demarca uma importante diferença entre Freud e Bloch no que diz respeito à fantasia: a relação com o tempo. Em Bloch a dinâmica da fantasia aponta para o futuro, desejo daquilo que ainda não veio a ser. Freud (2015, p. 58) é categórico em afirmar que a fantasia transita entre passado, presente e futuro, contudo, suas análises voltam-se preferencialmente em relação ao passado. Não seria coincidência o texto sobre a fantasia começar com a brincadeira de criança? A arquitetura da fantasia diurna em Freud seria: o desejo utiliza-se do presente para projetar no futuro um modelo segundo o passado. As criações da fantasia são os sonhos diurnos; contudo, ele questiona: "deveríamos de fato tentar comparar o poeta com o 'sonhador no dia luminoso' e suas criações como sonhos diurnos?" (ibidem, p. 60).

Para responder a essa questão, Freud diferencia dois tipos de Dichter: os que se inspiram em temas prontos e os que produzem seus temas. Estes últimos são mais importantes para ele, pois a partir deles pôde fazer a crítica ao ego da modernidade, alegando que as produções literárias têm aí sempre um herói, que por artimanha dos poetas fica ileso mesmo diante de todas as peripécias e intempéries por que passa. Essa crítica o faz ligar o eu dos escritos poéticos ao eu-herói dos sonhos diurnos, denominando tais produções poéticas de egocêntricas. Entretanto, destaca-se em Freud, que os sonhos diurnos ingênuos se diferenciam largamente de várias criações artísticas ou poéticas. Nesse ponto, ele parte da relação entre fantasia e temporalidade para explicar a relação entre o sonhador e a produção poética: "[...] uma forte vivência atual deve despertar 
no poeta a lembrança de uma vivência antiga, em geral uma vivência infantil, da qual então parte o desejo que será realizado na criação literária [Dichtung]" (ibidem, p. 62). Segundo ele, as próprias obras podem testemunhar a favor desse argumento. Mesmo reconhecendo a precariedade dessa argumentação, ele sustenta que ela pode ser fecunda. Isso foi feito por ele em seu escrito estético sobre Leonardo da Vinci: Uma lembrança de infância de Leonardo da Vinci, de 1910. Bloch refutará essa tese com veemência, principalmente quando Freud a reforça dizendo que "[...] as lembranças infantis na vida do poeta derivam, em última instância, da pressuposição de que a criação literária, como o sonho diurno, é uma continuação e uma substituição, a uma só vez, das brincadeiras infantis" (ibidem, pp. 62-63).

Segundo Freud, há ocultamento nos sonhos diurnos; se tentássemos comunicá-los, não causariam nenhum prazer. Mas o poeta, por outro lado, nos faz sentir prazer nos mais absurdos sonhos diurnos. Essa arte é unicamente do Dichter, por isso a arte é necessária, mesmo diante do segredo da Ars poetica, que, segundo Freud, está na capacidade do Dichter pela qual ele "[...] suaviza o caráter do sonho diurno egoísta por meio de alterações e ocultamentos, e nos espicaça por meio de um ganho de prazer puramente formal, ou seja, estético, o qual ele nos oferece na exposição de suas fantasias" (ibidem, p. 64). Ganho que ele considera como prazer para um prazer maior, um prazer preliminar [Vorlust].

Seria a função do sonho diurno nos proporcionar um prazer apenas formal? Esse caráter antecipador do prazer ao qual Freud se refere não nos levaria a um formalismo da imaginação? Essa descoberta de Freud não reforçaria a arte como ilusão, já que o prazer é de ordem puramente individual e passageiro? Essas são algumas questões respondidas por Bloch em sua apropriação e aprofundamento do sonho diurno. A tese de Freud de que o reino psíquico da fantasia é desvinculado do princípio da realidade reforça a crítica de Bloch à determinação da arte como puramente contemplativa, puro jogo imaginativo e descomprometido com o real. Para ele "se a arte fosse em toda parte e em todo tempo o mesmo que pura e descompromissada contemplação formal, [...] então a doutrina do parque de preservação ambiental estaria correta, e a ela se somaria um tipo de liberdade de loucos com o propósito de proporcionar prazer" (Bloch, 2005, p. 99).

A ligação da fantasia com o futuro nos sonhos acordados tem na obra de arte seu testemunho forte, pois essa antecipação em imagens poéticas não é uma bolha de sabão, mas possui ligação com o real. As imagens do desejo surgidas nas obras têm na quarta característica dos sonhos diurnos de ir até $o$ 
fim, apresentada acima, uma fundamentação precisa, uma vez que a arte leva até o fim suas fantasias.

[...] a vontade de ir até o fim bem-sucedido sempre perpassa a consciência utópica, colore essa consciência com inesquecíveis seres de contos de fadas, e vigora ainda nos sonhos de uma vida melhor, mas a suo modo também nas obras de arte, o que finalmente tem de ser compreendido. A fantasia de melhoria do mundo aterrissa nelas não apenas de modo que todos os seres humanos e coisas sejam conduzidas até o limite de suas possibilidades com todas as situações esgotadas e detalhadas em sua forma (Ibidem, p. 99, grifos do autor).

Bloch reconhece a descoberta de Freud, e critica o fato de os sonhos acordados e a arte terem sido por ele desfigurados pelo conceito de sublimação, visto que a eternidade das obras depende deles. Segundo nosso autor, a dimensão desse sonho não é sublimada, mas utópica: "o sonho diurno como prelúdio da arte visa assim, de maneira especialmente significativa, à melhoria do mundo; é esta aspiração saudável e realista que constitui seu cerne [...]" (ibidem, p. 96, grifos do autor). Para Bloch a arte contém dentro de si a privação que os humanos têm na vida real, mas isso não implica uma determinação, e sim uma prova de que a arte não está desvinculada da realidade concreta, ela carrega em si a utopia, não provocando no humano apenas um prazer preliminar, mas uma paisagem pintada em cores do possível-real, pois "na grande arte, os seres humanos e as situações são levados à última consequência em virtude do sonho diurno levado até o fim: o consequente e objetivamente possível torna-se visível" (ibidem, p. 96, grifos do autor). No sonho diurno existe o elemento utópico subjetivo fundamental tanto à arte quanto à ciência, pois a expansão do mundo e do próprio sujeito para a frente tem na luz do dia sua mola propulsora subjetiva: a fantasia objetiva, os sonhos acordados. Quando Bloch cita os poetas realistas e o sonho de uma coisa de Marx, tem em mente o interesse revolucionário, porque este interesse não quer o mundo como está, tampouco naturalizar a História. As coisas não estão bem, o homem sente isso, ele precisa transgredir esse momento. Os sonhos acordados fazem esse primeiro movimento. Segundo a interpretação de Ueding (1974, p. 11, tradução nossa) "na prática o sonho diurno mantém sua conexão com a realidade do processo: nela não está a teoria e a ação da letra, mas a imagem e o intensificador de seu alvo".

É somente nos sonhos diurnos que a arte encontra subsídios para sua existência? Só a fantasia diurna serve ao artista de matéria subjetiva? Seria imprudente afirmar isso. Bloch não descarta a relação existente entre sonhos diurnos e sonhos noturnos; mesmo sendo diferentes um do outro, segundo ele, "há na noite um jogo de cores que também pode existir durante o dia, que 
se parece com algo raro e, sem dúvida, também pode ser representado dessa forma" (Bloch, 2005, p. 101). A literatura e a arte transitaram e transitam pelas duas esferas dos sonhos, o que impede qualquer reducionismo da arte a uma esfera única dos sonhos. A diferença se dará necessariamente no conteúdo da obra de arte, se ela possui fragmentos utópicos, ou, ao contrário, é apenas um adorno para ser contemplado nas galerias de arte. Bloch não nega o intercâmbio entre esses dois tipos de sonhos. O romantismo alemão ${ }^{7}$ é um dos exemplos de movimento no qual ele percebe esse intercâmbio: "[...] entre os antípodas noite e luz do dia: cada um deles parece estar totalmente imerso no outro, ambos lúgubre e singularmente pressagiosos. Com quanta afinidade até mesmo o Romantismo pôde se valer dessa luz mista, como jogo onírico e não só como jogo" (Bloch, 2005, p. 101, grifos do autor).

Na visão de Bloch, no Romantismo chegou-se a uma má compreensão das diferenças entre sonhos noturnos e fantasias diurnas ${ }^{8}$ devido às suas imbricações: "o romântico puro já nem quer saber se na sua poesia predomina o caos inconsciente ou a fantasia conscientemente conformadora, transformadora" (ibidem, p. 102). O Romantismo tem sua importante contribuição nessa relação entre as formas de sonhos e a produção artística, mas é no Expressionismo e no Surrealismo que Bloch percebe o intercâmbio entre as fantasias diurnas e noturnas, diferenciando esses dois movimentos do Romantismo alemão pelo fato "[...] de que o utópico não queria se voltar tanto para o passado quanto o passado para o utópico" (idem). Para ele, "[...] traços noturnos foram integrados às linhas utópicas" (idem) na poesia expressionista, mesmo que neste movimento tenha havido o que ele chama de tom lunar. Também o que ela tem de nonsense foi trazido para o dia como elemento para ampliar os horizontes do cotidiano diurno rumo ao melhor. Um exemplo de imbricação entre sonhos diurnos e noturnos nessas produções criativas é apontado por Bloch no Ulisses de James Joyce.

7 Obra testemunhal sobre esse tema é a de Albert Béguin (1960).

8 Essa má compreensão das diferenças entre sonhos noturnos e fantasias diurnas destacada por Ernst Bloch não pode ser compreendida como uma negação total do Romantismo alemão, visto que este movimento tem implicações decisivas na totalidade do projeto filosófico de Bloch. Michael Löwy (1985) demonstra a forte influência do Romantismo no pensamento de Bloch e Lukács, apontando que as primeiras obras desses filósofos são marcadas pelo espírito revolucionário desse movimento, como por exemplo, Espírito da utopia (1918) e A teoria do romance (1916). Löwy também destaca a potência da filosofia de Bloch e de Lukács quando o romantismo e o marxismo se encontraram em suas filosofias. Para maior aprofundamento desse tema, deixamos a referência do escrito de Löwy (1985). Gostaria ainda, de indicar o artigo Pré-aparência (VorSchein) e enigma (Rätsel) na obra de arte: utopia e estética em Ernst Bloch e Theodor W. Adorno (Rodrigues, 2016) em que aponto a relação entre Romantismo e lluminismo em Bloch e Adorno desde Löwy (2009). Por fim, agradeço ao parecerista ad hoc da Revista Kriterion pela leitura crítica deste artigo e indicação do texto Le romantisme revolucionnaire de Bloch et Lukács de Michael Löwy (1985) para esclarecimentos sobre a relação de Bloch com o Romantismo Alemão. 


\section{Considerações finais}

Demonstra-se com os argumentos acima a força utópica da fantasia diurna, a potência filosófica dos sonhos diurnos que levam até o fim suas imagens, pois o passado não liquidado tem na força da fantasia diurna sua possibilidade de reavivamento e realização. O Surrealismo é para Bloch um exemplo dessa força produtiva que não desconsidera as forças da fantasia noturna, mas as usa para ir além, para trazer do passado as forças ainda não liquidadas para a luz da transformação do que é, e de como deveria ser. Assim, "o labirinto do sonho noturno não é nem mesmo esteticamente um prelúdio do castelo no ar, mas, enquanto aquele for o porão deste, o arcaico pode se comunicar com a fantasia desperta" (Bloch, 2005, p. 103). Bloch refuta a tese de Freud e ao mesmo tempo se apropria dela aprofundando-a. A comunicação entre as duas esferas do sonho é possível "[...] porque, não só psicológica, mas também objetivamente, um futuro ainda está vivo no passado, porque também muitos conteúdos noturnos não foram quitados nem estão prontos e por essa razão exigem o sonho diurno, a intenção para a frente" (idem, grifos do autor). Mesmo existindo imbricações entre os dois sonhos, as fantasias do sonho noturno só têm sentido se forem iluminadas pela fantasia do sonho diurno. Não haveria aqui uma redução como fez outrora Freud? Bloch traz o arcaico para a luz do dia, arcaico não liquidado. Por ser o sonho diurno o lugar do ego desperto e do controle da fantasia, a relação entre o arcaico e a utopia, segundo Bloch, amplia a função utópica.

Bloch não nega as descobertas de Freud ou da psicanálise, mas alarga o conceito de sonho diurno e coloca em segundo plano conceitos como libido e pulsões sexuais, pois, no lugar da regressão, ele coloca a expansão para frente e o novo; no lugar do inconsciente como única fonte de sentido para o sonho noturno e os enigmas do sujeito, ele coloca o ainda-não-consciente. Assim, na busca do novo fundado subjetivo e objetivamente, ele utiliza a tese freudiana do sonho como realização de um desejo no sentido do para a frente, para os sonhos diurnos, ou ainda, para a luz do dia. Isso reverbera diretamente em sua estética, principalmente na conexão entre as fantasias e o exterior e na questão do tempo, visto que ele coloca num lugar privilegiado o sonho acordado como primeiro momento da consciência antecipadora. Mas os sonhos diurnos são o começo, o ainda-não-consciente se anuncia e a consciência antecipadora surge como lugar de um pensamento transgressivo na estética marxista. Isso porque, mesmo estando em um determinado tempo e espaço históricos, os sonhos diurnos os transcendem, tornando-se assim o alicerce de uma antropologia de potencialidades utópicas, como afirma Catherine Piron-Audard (1976, p. 109) "[...] é necessário reabilitar, dentro do marxismo, uma antropologia da 
imaginação constitutiva e da esperança militante". Estamos diante de uma antropologia transgressiva, constante transgressão do humano rumo à sua completude e ao mundo melhor e mais bonito, e, nesse sentido, as obras de arte, prenhes de sonhos acordados, podem nos ajudar na construção deste mundo, mesmo que seja como doadoras de sentidos do ainda-não-consciente do futuro nas obras do passado e do presente.

\section{Referências}

ALBORNOZ, S. "Ética e Utopia: ensaio sobre Ernst Bloch”. Porto Alegre: Movimento, 1985.

BÉGUIN, A. "L'ame romantique et le revê: essai sur le romantisme allemande et la poésie française". Paris: Libraire Jose Corti, 1960.

BICCA, L. "Marxismo e Liberdade". S. Paulo: Loyola, 1987.

BLOCH, E. "O princípio esperança". Vol. I. Trad. Nélio Schneider. Rio de Janeiro: EDUERJ: Contraponto, 2005.

FREUD, S. “As fantasias histéricas e sua relação com a bissexualidade (1908)". In: Obras Completas - Vol. 8. O Delírio e Os Sonhos na Grádiva, análise da fobia de um garoto de cinco anos e Outros Textos (1906-1909). Tradução de Paulo César de Sousa. $1^{\text {a }}$ Ed. São Paulo: Companhia das Letras, 2015.

. "A interpretação dos sonhos Vol. I". Tradução de Renato Zwick. Porto Alegre, RS: L\&PM POCKET, 2017.

. “A interpretação dos sonhos Vol. II". Tradução de Renato Zwick. Porto Alegre: L\&PM POCKET, 2012.

. "O poeta e o fantasiar". In: Freud: arte, literatura e os artistas. Tradução de E. Chaves. Belo Horizonte: Autêntica, 2015. pp. 53-66.

. "Apresentação de THE PSYSICHOLOGY OF DAY-DREAM, DE J. VARENDONCK". In: Psicologia das massas e outros textos (1920-1923). Tradução de P. C. Sousa. São Paulo: Companhia das Letras, 2011.

LÖWY, M. "Ernst Bloch e Theodor Adorno: luzes do Romantismo". Cadernos Cemarx, Campinas, Nr. 6, pp. 11- 27, 2009. Disponível em: https://econtents.bc.unicamp.br/ inpec/index.php/cemarx/article/view/10772. Acesso em: março de 2013.

. "Le romantisme revolucionnaire de Bloch et Lukács". In: GOETHE INSTITUT.

Réification et utopie: Ernst Bloch et Georg Lukács un siècle après. Paris: Actes du colloque Goethe Institut, 1985. pp. 102-114.

MACHADO, C. E. Jordão. "Ernst Bloch e 'o sonho de uma coisa"'. In: Pensamento Alemão no século XX: grandes protagonistas e recepção das obras no Brasil. Vol. I. ALMEIDA, J.; BADER, W. (Orgs). São Paulo: Cosac Naify, 2009.

MÜNSTER, A. "Figures de l'utopie dans La pensée d'Ernst Bloch". Paris: Hermann Philosophie, 2009.

. "Utopia, Messianismo e Apocalipse nas primeiras de Ernst Bloch". Tradução brasileira de F. B. Siebeneichler. São Paulo: UNESP, 1997. 
PIRON-AUDARD, C. “Antropologie marxiste et psychanalyse selon Bloch". In. RAULET, G. Utopie - Marxisme selon Ernst Bloch: un système de l'inconstructible. Paris: Payot, 1976. pp. 109-122.

RODRIGUES, U. M. "Pré-aparência (Vor-Schein) e enigma (Rätsel) na obra de arte: utopia e estética em Ernst Bloch e Theodor W. Adorno." Philósophos - Revista De Filosofia, 21(1), pp. 189-212, 2016. https://doi.org/10.5216/phi.v21i1.39743._Disponível em: https://revistas.ufg.br/philosophos/article/view/39743. Acesso em: 26 de dezembro de 2020.

UEDING, G. "Tagtraum, künstlerische Produktivität und Werkprozeß”. In: Ernst Bloch, Ästhetik des Vor-Scheins. Frankfurt/M: Suhrkamp Verlag, 1974. Bd. 2.

ZECCHI, S. "Ernst Bloch: Utopia y Esperanza en el Comunismo". Tradução espanhola de Enric Pérez Nadal. Barcellona: Península, 1978. 